\title{
Adaptive rehabilitation management and a drying climate: unique challenges for Alcoa's bauxite mine rehabilitation in southwestern Australia
}

\author{
A. Grigg Environmental Research Department, Alcoa of Australia, Australia
}

\begin{abstract}
Alcoa has been mining bauxite in Perth's water supply catchments within the jarrah forest of southwest Australia since the late 1960s and has rehabilitated more than 15,000 ha to date. The current rehabilitation objective of restoring a sustainable jarrah forest ecosystem was implemented from 1988, utilising direct seeding of the local native tree species of jarrah (Eucalyptus marginata) and marri (Corymbia calophylla). Tree establishment densities were initially high, averaging 3,000 trees $\mathrm{ha}^{-1}$, but these have been reduced over time as an adaptive management response based on monitoring and feedback. The present day establishment target is 1,300 trees $\mathrm{ha}^{-1}$, with a maximum of 2,500 trees $\mathrm{ha}^{-1}$. Although tree densities meet past and current completion criteria agreed to by regulators, there is reluctance on the part of some government stakeholders to grant Certificates of Acceptance because of the higher water use characteristics of dense rehabilitation compared to the less dense forest it replaced. The issue has risen in prominence in recent years due to declining water yields into Perth's water supply reservoirs, which are largely associated with a drying climate since the mid 1970s. While target tree establishment densities for future years of rehabilitation may be reviewed in renegotiated completion criteria, a legacy remains of older rehabilitation which is now regarded as over-dense. Alcoa believes that these areas may be treated by an initial cycle of thinning, which experimentation at the plot and whole-catchment scale has demonstrated: (i) increased catchment flows; (ii) potentially shortened crop rotations for future timber production; and (iii) benefits to forest conservation values including fauna. This paper describes the unique challenges faced by Alcoa and the rare example of large-scale post-establishment management of rehabilitation to address stakeholder concerns and to deliver improved rehabilitation outcomes.
\end{abstract}

\section{Introduction}

Alcoa has been mining bauxite in Perth's water supply catchments within the jarrah forest of southwest Australia since the 1960s, with an anticipated life of operations for another 40-50 years (Gardner and Bell, 2007). The first rehabilitation occurred in 1966 and since then more than 15,000 ha have been rehabilitated. This estate increases by about 600 ha annually. The current rehabilitation objective of restoring a sustainable jarrah forest ecosystem was implemented from 1988, utilising direct seeding of the local native tree species of jarrah and marri. Long-term monitoring and research provides a feedback mechanism by which practices can, and have been, adjusted over time (Koch, 2007).

Mining restoration efforts typically focus on the successful establishment of a vegetation cover, with less consideration given to its longer-term development or management for future land uses. This case study shows that, in the unique context of bauxite mining in the south west of Australia, longer term intervention may be required to direct restoration/reclamation efforts towards desired end uses. A drying climate provides additional stimulus to this review and adaptation. This paper describes the unique challenges faced by Alcoa and the rare example of large-scale post-establishment management of rehabilitation to address stakeholder concerns and to deliver improved rehabilitation outcomes. 


\section{Environmental setting: the jarrah forest, a drying climate and forest thinning}

The jarrah forest covers much of the south west of Western Australia, a region that experiences a strongly Mediterranean climate with most of the $600-1,300 \mathrm{~mm}$ of annual rainfall falling between April and October (Gentilli, 1989). There is a strong geographic gradient in rainfall, being highest on the western margin of the forest along the Darling Scarp and on the southern coast, but declining rapidly with distance inland. To cope with seasonal drought, the jarrah tree relies on an extensive root system (Dell et al., 1983) to obtain water from the typically deep soils (up to $30 \mathrm{~m}$ ) to maintain transpiration throughout the year (Crombie et al., 1988; Macfarlane et al., 2010a). As a consequence of such a large soil water store, the jarrah forest is described as 'producing little streamflow from moderate rainfall' (Schofield et al., 1989). In the higher rainfall areas, streamflows from water supply catchments were historically in the order of $7 \%$ of rainfall (Ruprecht and Stoneman, 1993), while in the drier inland parts of the forest virtually all rainfall is lost through evapotranspiration (Schofield et al., 1989).

Against a setting of increasing demand for water due to an increasing population, streamflows in Perth's water supply catchments have declined by up to $70 \%$ over the past 40 years (Petrone et al., 2010). The decline is associated with a $15-20 \%$ reduction in annual rainfall and an increasing frequency of drier than average rainfall years. Low rainfall years are shown to cause step declines in catchment groundwater levels (Petrone et al., 2010) which are important in determining catchment runoff and runoff ratios (Stoneman, 1993; Hughes et al., 2012). Consequently, streamflow from a given annual rainfall is now far lower than that produced in earlier years (Hughes et al., 2012). Many streams that were previously perennial are now seasonal, raising concerns not only for human water supplies but also for the conservation of streamzone biodiversity.

The possibility of forest management, and specifically forest thinning, to increase streamflows in the jarrah forest has been recognised for some time (Stoneman and Schofield, 1989). The magnitude and timing of streamflow response to any forest treatment is dependent on the degree of forest reduction and average rainfall (Stoneman and Schofield, 1989), and on the level of the groundwater table relative to the surface (Ruprecht and Stoneman, 1993; Kinal and Stoneman, 2011). Stoneman and Schofield (1989) also highlighted the potential of forest thinning to improve overly-dense jarrah regrowth stands resulting from historical forest harvesting, since jarrah is naturally slow to self-thin. Thus, thinning is recognised as a tool to benefit not only water yields but also future timber production in native jarrah forests. A large-scale trial is presently in progress within the Wungong water supply catchment to test these ideas (Water Corporation, 2005). The recent record drought of 2010 has led to speculation within this trial that thinning is desirable simply to maintain the health of the remaining trees (Batini, 2012).

\section{Bauxite mine rehabilitation prescriptions and practices: adaptive management}

Alcoa has been rehabilitating areas mined for bauxite in the jarrah forest since the late 1960s, adopting improvements in practices as experience and new knowledge is gained. Early efforts were directed at reinstating a productive forestry land-use, utilising a range of commercially valuable eucalypt species from eastern Australia (Gardner and Bell, 2007). The return of jarrah was not considered appropriate due to the threat of poor survival from the soil-borne pathogen Phytophthora cinnamomi. However, feedback from monitoring and targeted experimentation found the risk to be overstated, contributing to the adoption in 1988 of the present rehabilitation objective of returning a sustainable jarrah-dominant forest ecosystem supporting a range of forest uses (Gardner and Bell, 2007).

All rehabilitation since 1988 has returned a mix of jarrah and marri (Corymbia calophylla) in the overstorey, utilising direct seeding techniques rather than the planting of nursery-raised tubestock used earlier (Koch, 2007; Koch and Samsa, 2007). The success of direct seeding of tree species was uncertain at the time, with highly variable germination/establishment rates (Koch and Samsa, 2007) and the suggestion that seedling 
emergence in open mine pits may have been lower than under an existing canopy (McChesney et al., 1995). The survival of germinated seedlings through the early summer droughts was also poorly understood, as was the proportion of established seedlings that developed into saplings versus ground coppice which are common in the native unmined forest (up to 10,000 seedlings/ha) but remain suppressed by the overstorey trees (Koch and Samsa, 2007). These factors led to early seed application rates of combined eucalypt species in the range 1.5-3.7 kg/ha (Figure 1), with tree densities (measured nine months after sowing) averaging approximately 3,000 trees $\mathrm{ha}^{-1}$ and even higher during the early-mid 1990s (Figure 2). This compares with the requirement under the agreed Completion Criteria of the time to establish a minimum of 300 trees/ha that were of a suitable quality for future sawlog production (Elliot et al., 1996).

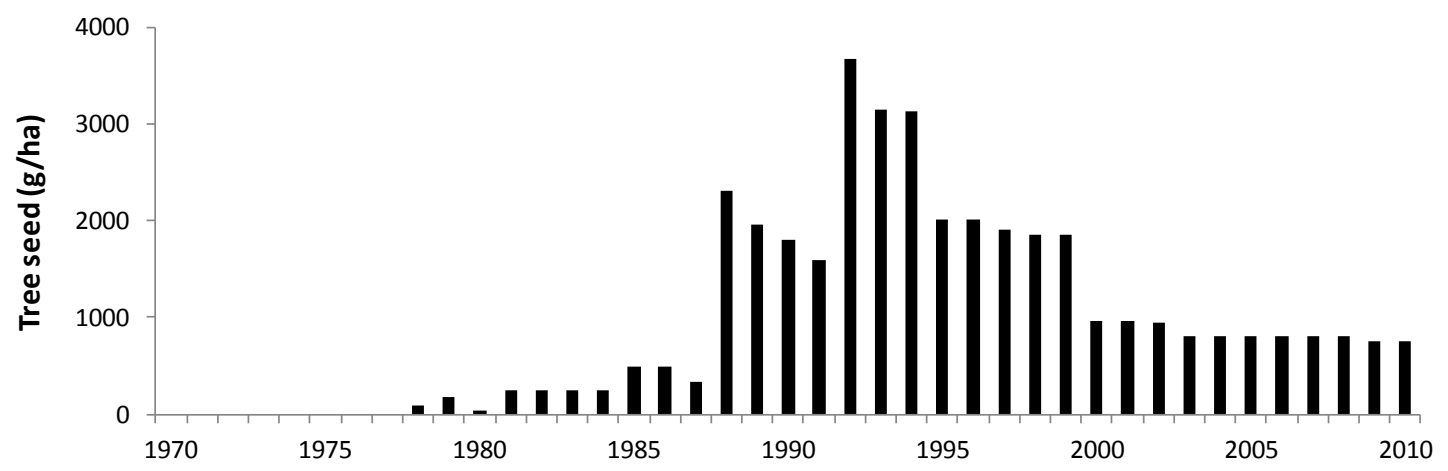

Figure 1 Seed application rate for jarrah and marri by year of rehabilitation

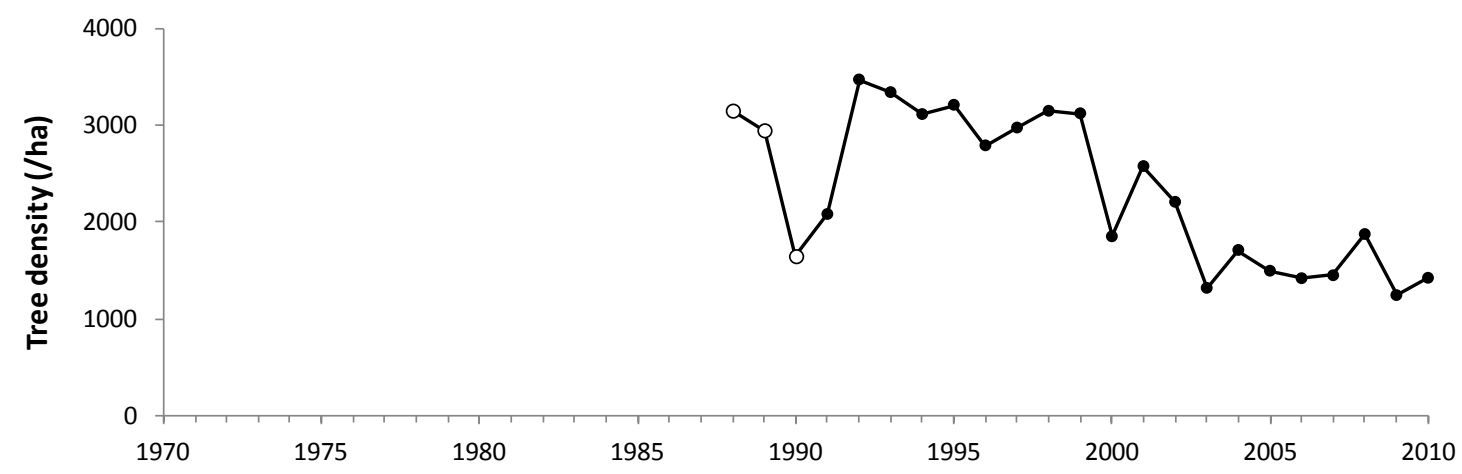

Figure 2 Combined overstorey tree mean establishment density by year of rehabilitation. Closed symbols indicate results are from routine pit monitoring conducted at nine months; earlier years are estimates based on permanent plot results and seed records

Ongoing annual monitoring of eucalypt establishment (Figure 2), combined with results of dedicated trials, subsequently showed that survival of jarrah in rehabilitation is high, reported at $96 \%$ after two summers (Ward and Koch, 1995) and typically exceeding 80\% after nearly 30 years (Koch and Samsa, 2007). Only where stocking is $>8,000 \mathrm{stems} / \mathrm{ha}$ is survival decreased (Koch and Ward, 2005). Seed application rates were reduced to less than $2 \mathrm{~kg} / \mathrm{ha}$ by 1997 and subsequently halved to less than $1 \mathrm{~kg} / \mathrm{ha}$ in 2000 (Figure 1).

Alcoa's completion criteria are subject to review on a five yearly basis, enabling their adjustment and refinement with the accumulation of new knowledge. The Criteria developed in the mid-1990s were revised in 2002 (DolR, 2002), at which time a target density of 1,300 trees ha ${ }^{-1}$ and an upper limit of 2,500 trees ha-1 were introduced. These changes reflected a better understanding of the relationship between seed application rates and establishment (Figure 3), survival rates, the effects of initial establishment densities on tree form (affecting sawlog quality) and the developmental trajectories with age of the rehabilitation stands (Grant, 2006). Since 2003, establishment eucalypt densities have been close to the target (Figure 2), with an average of 1,490 trees ha- ${ }^{-1}$, however, there exists a legacy of over 6,000 ha of rehabilitation spanning a period of more than a decade (1988-2002) with a pit mean establishment density of approximately 2,800 trees ha-1. 


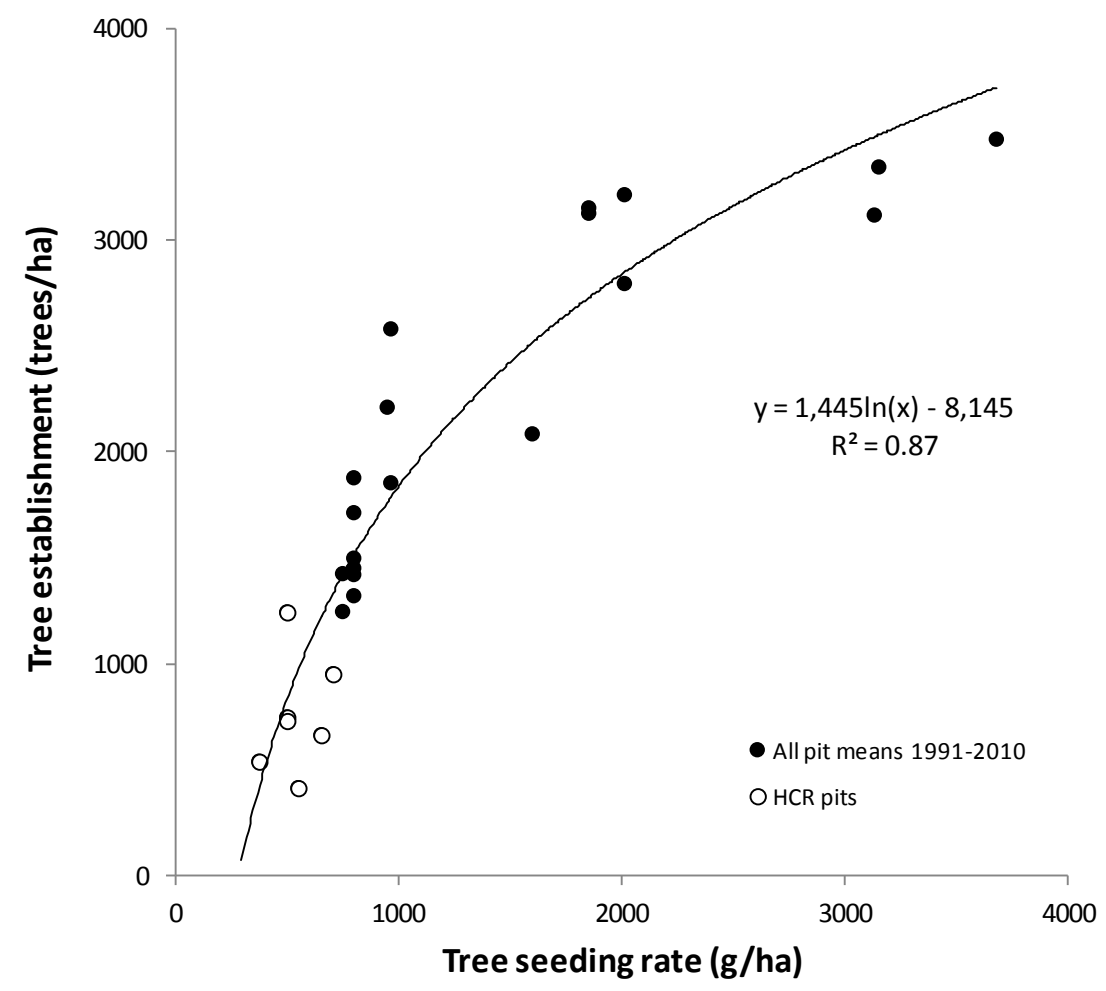

Figure 3 Relationship between seeding rate and establishment density (measured at nine months) for bauxite mine rehabilitation. Demonstration pits denoted 'HCR pits' featuring reduced seeding rates are described in more detail in the text

The hydrological effects of mining on a catchment scale follow a typical pattern, described by Croton and Reed (2007). Streamflows initially increase with the advent of clearing for mining, then return to pre-mining levels as the rehabilitation develops. A continuing decline in flows is observed in some catchments, typically where the density of the rehabilitation exceeds the density of the pre-mining forest; catchments with dense forest before mining do not show this latter stage. Such observations prompted the establishment in 2009 of demonstration pits, dubbed 'Hydrologically Considerate Rehabilitation (HCR)', to trial a range of treatments aimed at decreasing the overall availability of water within mine pits and subsequent use by vegetation. One of the treatments being tested is a reduced application rate of both tree and understorey seed. Early monitoring has indicated lower establishment densities of overstorey trees than the present prescription, consistent with seeding rates (Figure 3).

\section{$4 \quad$ Responses to thinning of rehabilitation}

Silvicultural treatment of rehabilitation stands now considered as over-dense has the potential to deliver both increased stream yields and improved growth of remaining trees, as observed in the native jarrah forest. A number of rehabilitation thinning experiments and related studies have been conducted over the past decade, aimed not only at determining the effects of thinning on streamflows in mined catchments but also the effects on a range of ecosystem attributes. The outcomes of some of these studies are summarised.

\subsection{Effects of thinning on streamflow}

A thinning trial was established in two adjacent small (approximately 85 ha) headwater catchments, Warren and Bennett's, in 2007 and is currently ongoing. Approximately half of each catchment was mined during the late 1980s and rehabilitated over three years 1990-1992, which includes the year with the highest average tree establishment densities (Figure 2). Previous analysis had indicated that flows in both catchments are now below pre-mining levels (Croton and Reed, 2007). Thinning by notching was 
undertaken in April-May 2007 in rehabilitated areas only within the Bennett catchment, with a follow-up treatment in September 2008 to further reduce stand basal area (Table 1). A controlled burn in early November 2007 removed most of the understorey but crown scorch was limited. Leaf area index, a measure of vegetation density, was reduced from approximately 2.2 to around 1.3 immediately after the burn, on a catchment average basis.

\section{Table 1 Stand characteristics of rehabilitation in Bennett catchment prior to thinning} (January 2007) and after two rounds of thinning

\begin{tabular}{|c|c|c|c|c|c|c|c|}
\hline \multirow[b]{2}{*}{$\begin{array}{c}\text { Year of } \\
\text { Rehabilitation }\end{array}$} & \multirow[b]{2}{*}{$\begin{array}{l}\text { Area } \\
\text { (ha) }\end{array}$} & \multicolumn{2}{|c|}{ Pre-Thin } & \multicolumn{2}{|c|}{ 1st Thin } & \multicolumn{2}{|c|}{ 2nd Thin } \\
\hline & & $\begin{array}{l}\text { Mean } \\
\text { Stocking }\end{array}$ & $\begin{array}{l}\text { BAOB } \\
\left(\mathrm{m}^{2} / \mathrm{ha}\right)\end{array}$ & $\begin{array}{l}\text { Mean } \\
\text { Stocking }\end{array}$ & $\begin{array}{l}\text { BAOB } \\
\left(\mathrm{m}^{2} / \mathrm{ha}\right)\end{array}$ & $\begin{array}{l}\text { Mean } \\
\text { Stocking }\end{array}$ & $\begin{array}{l}\text { BAOB } \\
\left(\mathrm{m}^{2} / \mathrm{ha}\right)\end{array}$ \\
\hline 1990 & 9.6 & 1,075 & 20.6 & 700 & 15 & 463 & 9.6 \\
\hline 1991 & 19.0 & 2,020 & 27.1 & 1,200 & 20.9 & 800 & 15.5 \\
\hline 1992 & 10.7 & 3,870 & 40.4 & 1,475 & 27.3 & 990 & 17.2 \\
\hline All years & 39.2 & $2,300 *$ & $29.2^{*}$ & $1,155^{*}$ & $21.3^{*}$ & $770 *$ & $14.6 *$ \\
\hline
\end{tabular}

"*" weighted means.

BAOB: basal area over bark.

Streamflow response was estimated by a double mass curve analysis (see Mu et al., 2010) utilising the long pre-thinning record which commenced in 1978. A thinning response of $31 \mathrm{~mm}$ was estimated for the winter immediately following initial treatment, with additional streamflows in 2008 and 2009 of $31 \mathrm{~mm}$ and $41 \mathrm{~mm}$ respectively. Total flow in 2009 in Bennett catchment of $115 \mathrm{~mm}$, equating to a rainfall runoff ratio of more than $9 \%$, was the highest in almost a decade (Figure 4). Nearly all of the additional streamflow occurred in the months June-September. Further response in 2010 and 2011 was truncated by an extreme drought year in 2010 ( $638 \mathrm{~mm}$ compared to a long-term average of approximately 1,250 mm), which presumably caused a step-decline in catchment groundwater levels and consequent effects on runoff ratios (Hughes et al., 2012). Runoff ratios in both catchments were less than 2\% for 2010 and 2011.

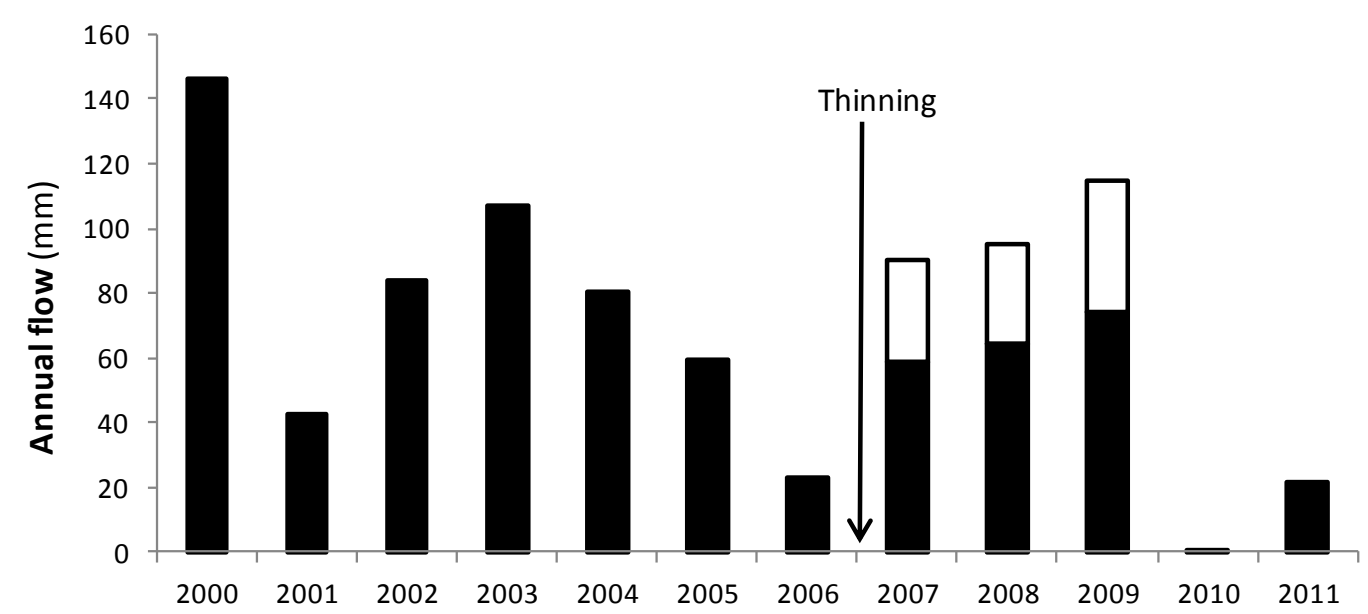

Figure 4 Annual streamflow in Bennett catchment over the past 12 years, with estimated response to thinning shown as open bars

\subsection{Effects of thinning and burning on tree growth}

Jarrah in densely stocked rehabilitation stands shows reduced height and diameter growth (Koch and Ward, 2005) due to intense competition. In young 10-13 year old rehabilitation, Grigg and Grant (2009) showed that thinning increased the growth rate of retained trees, from $0.48 \mathrm{~cm} /$ year diameter under bark in the four years following treatment up to $1.44 \mathrm{~cm} /$ year when thinned to 400 trees ha $^{-1}$, with further increases under fertiliser application. Thinning in these stands to approximately 1,100 trees ha $^{-1}$ maximised stand 
basal area growth, although the heaviest thinning to 400 trees ha ${ }^{-1}$ still yielded approximately $75 \%$ of the maximum stand basal area growth and increased the diameter growth of the best 100 retained trees/ha from $1.4 \mathrm{~cm} /$ year to $2 \mathrm{~cm} /$ year (under bark), which potentially shortens crop rotation. The study found that heavier thinning also extended the period that canopy leaf area index remained below pre-thinning levels. Since leaf area index is related to stand water use, a heavier thinning would be expected to result in a longer catchment streamflow response. Coppice control from the stumps of felled trees will be important, as coppice regrowth can be substantial (Abbott and Loneragan, 1983; Grigg and Grant, 2009).

A burning treatment (applied in autumn) in this study reduced tree growth response to thinning and fertiliser application (Grigg and Grant, 2009). This was attributed to cambial damage arising from relatively hotter burns due to increased fuel loads from thinning slash (Grigg et al., 2010), but noting that no attempt was made to clear larger diameter thinning slash away from retained trees.

\subsection{Response of other ecosystem attributes to thinning and burning}

Grant and Norman (2006) studied the response of the understorey to thinning and burning treatments in 10-13 year old rehabilitation. They found that, of 23 measured understorey parameters, only Sorenson's index of similarity was significantly affected and only at the heaviest thinning intensity ( 400 stems ha- $^{-1}$ ). Heavily thinned sites had a greater increase in the number of weed species compared to lighter thinning treatments, assessed 18 months after treatment. Burning caused a greater change in understorey composition. Burning (in autumn) increased species richness, in part due to short-lived fire-response species which have been shown in earlier studies to decline to pre-burn levels within six years (Grant, 2003). Hard-seeded legume species and other heat responsive species were also stimulated, associated with hotter temperatures in the autumn burn. Stimulated by fire, and under conditions of reduced tree competition from thinning, these species contributed to dense regrowth and the rapid re-accumulation of fuel loads (Grigg et al., 2010) and understorey leaf area (Macfarlane et al., 2010b). Spring burning, although not tested in this experiment, was considered to result in a more muted response and has been recommended as the preferred burning season (Grant and Norman, 2006).

To assess the impact of thinning and burning on reptiles and small mammals, Craig et al. (2010) selected thinned and burned sites in both pre-1988 and post-1988 rehabilitation, each paired with untreated controls. They found that three years after treatment there was no significant impact on the small mammal community, although the pygmy possum (Cercatetus concinnus) was more abundant in rehabilitated sites. In contrast, thinning and burning significantly increased reptile abundance and species richness, with two skink species (Morethia obscura and Menetia greyii) only recorded in thinned and burned sites. They concluded that thinning and burning was a successful management option for densely revegetated mine pits in jarrah forests, particularly because reptile communities created by thinning and burning were more similar to those in unmined forest.

In studying the response of the soil microbial community to thinning and burning, Cookson et al. (2008) found that in the short-term, soil microbial communities were unaffected by burning but were altered by thinning. Changes to carbon and nutrient inputs via litter fall, interacting with soil properties, were thought to influence microbial nutrient demand and hence microbial community composition. Subsequent work has suggested that the main effect of thinning is to extend the period of change, presumably related to the longer time required for recovery in vegetation density and associated fluxes. However, the significance of such changes from a functional perspective is still being investigated.

\section{Current steps: towards operational-scale thinning of dense rehabilitation}

There are clearly multiple benefits to be derived from thinning of rehabilitation established with tree densities higher than the present target. In keeping with the ethos of high environmental standards and anticipating rather than reacting to community expectations, as espoused in Gardner and Bell (2007), Alcoa is developing plans and programs to undertake broadscale thinning of established rehabilitation areas. 
Initial steps have focussed on an inventory of the rehabilitation estate to capture attributes of management interest including tree stocking, tree size, estimates of wood volume and understorey density. At the same time, efforts are being directed at developing improved models of rehabilitation jarrah growth to assist in predicting longer-term development. Information from the thinning trials described above is also providing the basis for possible thinning prescriptions (eg. DEC, 2007). These are the early phases of an anticipated multi-year program of thinning, with many processes from physical on-ground activities to higher-level policy yet to be developed.

\section{References}

Abbott, I. and Loneragan, O.W. (1983) Response of jarrah (Eucalyptus marginata) regrowth to thinning, Australian Forest Research, Vol. 13, pp. 217-229.

Batini, F. (2012) Dry times in the jarrah forest, Landscope (Summer 2011-12) Department of Environment and Conservation.

Cookson, W.R., O'Donnell, A.J., Grant, C.D., Grierson, P.F. and Murphy, D.V. (2008) Impact of ecosystem management on microbial community level physiological profiles of postmining forest rehabilitation, Microbial Ecology, Vol. 55, pp. 321-332.

Craig, M.D., Hobbs, R.J., Grigg, A.H., Garkaklis, M.J., Grant, C.D., Fleming, P.A. and Hardy, G.E.StJ. (2010) Does thinning and burning sites revegetated after bauxite mining improve habitat for terrestrial vertebrates? Restoration Ecology, Vol. 18, pp. 300-310

Crombie, D.S., Tippett, J.T. and Hill, T.C. (1988) Dawn water potential and root depth of trees and understorey species in southwestern Australia, Australian Journal of Botany, Vol. 36, pp. 621-632.

Croton, J.T. and Reed, A.J. (2007) Hydrology and bauxite mining on the Darling Plateau, Restoration Ecology, Vol. 15, pp. S40-S47.

DEC (2007) Department of Environment and Conservation. Interim Guideline for the First Thinning of Bauxite Rehabilitation Areas Established After 1988 with Native Species in the Wungong Catchment, Department of Environment and Conservation SFM Interim Guideline No. 2.

Dell, B., Bartle, J.R. and Tacey, W.H. (1983) Root occupation and root channels of jarrah forest subsoils, Australian Journal of Botany, Vol. 31, pp. 615-627.

DoIR (2002) Department of Industry and Resources. Alcoa World Alumina Australia Darling Range bauxite mine rehabilitation completion criteria, Perth, Australia.

Elliot, P., Gardner, J., Allen, D. and Butcher, G. (1996) Completion criteria for Alcoa of Australia Limited's bauxite mine rehabilitation, in 3rd International and 21st Annual Minerals Council of Australia Environmental Workshop, Newcastle, pp. 79-89.

Gardner, J.H. and Bell, D.T. (2007) Bauxite mining restoration by Alcoa World Alumina Australia in Western Australia: social, political, historical, and environmental contexts, Restoration Ecology, Vol. 15, pp. S3-S10.

Gentilli, J. (1989) Climate of the jarrah forest, in The Jarrah Forest: a complex Mediterranean ecosystem, B. Dell, J.J. Havel and N. Malajczuk (eds), Kluwer Academic Publishers, Dordrecht, The Netherlands, pp. 23-40.

Grant, C.D. (2003) Post-burn vegetation development of rehabilitated bauxite mines in Western Australia, Forest Ecology and Management, Vol. 186, pp. 147-157.

Grant, C.D. (2006) State-and-transition successional model for bauxite mining rehabilitation in the jarrah forest of Western Australia, Restoration Ecology, Vol. 14, pp. 28-37.

Grant, C.D. and Norman, M.A. (2006) Investigating thinning and burning operations in 10 to 13 -year-old rehabilitated bauxite mines in the jarrah forest, Research Bulletin No. 35, Alcoa World Alumina Australia.

Grigg, A., Norman, M. and Grant, C. (2010) Prescribed burning of thinning slash in regrowth stands of jarrah (Eucalyptus marginata) following bauxite mining in south-west Australia, International Journal of Wildland Fire, Vol. 19, pp. 737-745.

Grigg, A.H. and Grant, C. (2009) Overstorey growth response to thinning, burning and fertiliser in 10-13-year-old rehabilitated jarrah (Eucalyptus marginata) forest after bauxite mining in south-western Australia, Australian Forestry, Vol. 72, pp. 80-86.

Hughes, J.D., Petrone, K.C. and Silberstein, R.P. (2012) Drought, groundwater storage and stream flow decline in southwestern Australia, Geophysical Research Letters, Vol. 39, L03408.

Kinal, J. and Stoneman, G.L. (2011) Hydrological impact of two intensities of timber harvest and associated silviculture in the jarrah forest in south-western Australia, Journal of Hydrology, Vol. 399, pp. 108-120.

Koch, J.M. (2007) Alcoa's mining and restoration process in south western Australia, Restoration Ecology, Vol. 15, pp. S11-S16.

Koch, J.M. and Samsa, G.P. (2007) Restoring jarrah forest trees after bauxite mining in Western Australia, Restoration Ecology, Vol. 15, pp. S17-S25.

Koch, J.M. and Ward, S.C. (2005) Thirteen year growth of jarrah (Eucalyptus marginata) on rehabilitated bauxite-mines in southwestern Australia, Australian Forestry, Vol. 68, pp. 176-185.

Macfarlane, C., Bond, C., White, D.A., Grigg, A.H., Ogden, G.N. and Silberstein, R. (2010a) Transpiration and hydraulic traits of old and regrowth eucalypt forest in southwestern Australia, Forest Ecology and Management, Vol. 260, pp. 96-105.

Macfarlane, C., Lardner, T., Patterson, K. and Grigg, A. (2010b) A new model for predicting understorey leaf area from biomass in eucalypt forest to test the ecohydrological equilibrium theory, Methods in Ecology and Evolution, Vol. 1, pp. 371-379.

McChesney, C.J., Koch, J.M. and Bell, D.T. (1995) Jarrah forest restoration in Western Australia: canopy and topographic effects, Restoration Ecology, Vol. 3, pp. 105-110. 
Mu, X.M., Zhang, X.Q., Gao, P. and Wang, F. (2010) Theory of double mass curves and its application in hydrology and meteorology, Journal of China Hydrology, Vol. 30, pp. 47-51.

Petrone, K.C., Hughes, J.D., Van Neil, T.G. and Silberstein, R.P. (2010) Streamflow decline in southwestern Australia, 1950-2008, Geophysical Research Letters, Vol. 37, L11401.

Ruprecht, J.K. and Stoneman, G.L. (1993) Water yield issues in the jarrah forest of south-western Australia, Journal of Hydrology, Vol. 150, pp. 369-391.

Schofield, N.J., Stoneman, G.L. and Loh, I.C. (1989) Hydrology of the jarrah forest, in The Jarrah Forest: a complex Mediterranean ecosystem, B. Dell, J.J. Havel and N. Malajczuk (eds), Kluwer Academic Publishers, Dordrecht, The Netherlands, pp. 179-201.

Stoneman, G.L. (1993) Hydrological response to thinning a small jarrah (Eucalyptus marginata) forest catchment, Journal of Hydrology, Vol. 150, pp. 393-407.

Stoneman, G.L. and Schofield, N.J. (1989) Silviculture for water production in jarrah forest of Western Australia: an evaluation, Forest Ecology and Management, Vol. 27, pp. 273-293.

Ward, S.C. and Koch, J.M. (1995) Early growth of jarrah (Eucalyptus marginata Donn ex Smith) on rehabilitated bauxite minesites in south-west Australia, Australian Forestry, Vol. 58, pp. 65-71.

Water Corporation (2005) Wungong Catchment Environment and Water Management Project, Water Corporation, Leederville, Western Australia. 